\title{
THE ROLE OF LIVONIAN IN LATVIA FROM A SOCIOLINGUISTIC PERSPECTIVE
}

\author{
Ina Druviete ${ }^{\mathbf{1}}$ and Gunta Kl̦ava ${ }^{\mathbf{1 , 2}}$ \\ ${ }^{1}$ University of Latvia and ${ }^{2}$ Latvian Language Agency
}

\begin{abstract}
This article examines the role of Livonian in present-day Latvia and describes the Livonian language situation in the context of Latvia's language situation and current sociolinguistic issues. It describes how Livonian language and culture are represented in Latvian law, along with possibilities for realising Livonian language rights, bringing attention to the Livonians as an ethnicity, and understanding issues relating to Livonian, while also describing the use of terminology in the Livonian context. The Livonians cannot exactly be described as a "minority". The Livonians are something more, they are a part of the modern Latvian language and also of Latvian culture and the culture of Latvia in general. And yet, the Livonian nation and language are independent entities. Therefore, the position of Livonian within Latvia should be seen from two perspectives: the preservation, development, and revitalisation of the use of Livonian as well as the mutual influence of Livonian and Latvian.
\end{abstract}

Keywords: language maintenance, language policy, language situation, language status, Latvian, Livonian

DOI: https://doi.org/10.12697/jeful.2018.9.2.06

\section{Introduction}

Livonian is an autochthonous language of Latvia, which is mentioned in the Latvian Official Language Law. There are very few speakers, researchers, or teachers of Livonian and it is listed in the UNESCO Atlas of the World's Languages in Danger as one of the most critically endangered languages in Europe. In assessing the vitality of any language, the first question concerns the number of people who speak and use that language: for Livonian this question is difficult to answer and determine for several different reasons. Though 250 people identified themselves as Livonian in the most recent census in Latvia (Census 2011), this fact does not mean that everyone who considers themselves to be Livonian speaks Livonian. Likewise, it does not mean that there 
are only 250 Livonians living in Latvia. Taking into account that the Livonian community has been entirely bilingual at least since the end of the 19th century (Ernštreits 2012: 156), and has now experienced complete language shift (Blumberga 2013: 194), the native language as this term is traditionally understood - for the majority of Livonians is Latvian, or for a few of them possibly also some other language.

Presently, Livonian is not inherited from generation to generation, it is not learned directly from one's parents, it is not the daily language of interaction in any family. However, this does not mean that there are no speakers of Livonian at all - among Livonian speakers today one can even find several for whom it is their native language. To be able to give a concrete number of Livonian speakers, it is necessary first to determine several statistical indicators for Livonian, which are currently not known. However, hopefully this situation will be improved with the recent founding of the University of Latvia Livonian Institute and following the realisation of its intended work plan and projects in the near future; these include documenting and describing the sociolinguistic situation of the Livonian language.

\section{Description of the Livonian language situation}

The 30 people mentioned above (Livones) who speak Livonian well include scientists and other interested individuals from research institutions around the world but who are not Livonians themselves; Livonian descendants who did not learn Livonian from their parents but from their grandparents; also those who learned Livonian from a fluent older speaker (not a family member) and through self-study. It may be that 30 is too large of a number if we evaluate these speakers using, for example, the language proficiency levels as defined by the Common European Framework of Reference for Languages (using their general principles, as a description of Livonian language proficiency levels is not, of course, currently available and for the time being is not even possible to generate). Descriptions of the language of the best speakers of Livonian cannot be made until these can be backed by research studies. It should also be noted that though the Livonian community is currently undergoing generational change, at this time it is still possible to find Livonian speakers who inherited their language from older generations of speakers. 
Another important aspect is the degree and quality of language proficiency, i. e., to put it more simply - knowing a few words in a language is not the same as knowing a language fully and, likewise, not knowing the structures and rules of a language does not mean that they do not exist in that language. And this does not have any connection with the prescriptivism that Livonian is characterised as having at times. As the compiler of the Livonian-Estonian-Latvian dictionary, Tiit-Rein Viitso, wrote in its foreword, Livonian is in a situation characterised by insufficient proficiency and language use; however, the quality of the Livonian used is also a significant problem. That is to say, a small number of speakers does not justify the often encountered practice of ignoring grammar rules when speaking (Viitso 2012: 12). However, the positive attitude and desire to show belonging to this community by using Livonian, even if one does not know very much of it, is significant and is also a motivating force for all matters relating to Livonian.

The enthusiasm and current number of those wishing to learn Livonian and interested in Livonian heritage, including those doing so using modern technology, is, if not growing, then at least very stable (Ernštreits 2017: 199). Taking into account the significant obstacles to learning Livonian (Ibid.: 205), the linguistic attitude and motivation of members of society is one of the most significant factors, which can maintain and promote the use of a language that has almost completely disappeared (Sarivaara, Uusiautti, Määttä 2013: 16). A good beginning is to use greetings in Livonian, but - that is not enough.

Much has been done for Livonian language development in the last decades. This has been especially the case following the wide-ranging programme of the Year of Livonian Language and Culture in 2011 (Ernštreits 2017: 196). Knowledge about the Livonians - their language, culture, and history - is broader and of better quality among Latvian society as a whole (Blumberga 2013: 203). The awareness among Livonians of their connection with their ancestral language and culture, hopefully is continuing to strengthen, as evidenced, for example, by children's summer camps, activity by younger people on social media, and so on. More information can be found on the most significant works relating to Livonian language development in the articles written by V. Ernštreits (Ernštreits 2012a, Ernštreits 2017, etc.) and hopefully these works are being used by the more active members of the Livonian community. For the time being, Latvian is used at every Livonian community event or activity, as the majority of community members, unfortunately, know very little Livonian and can only say a few greetings. For 
that reason, any speech delivered in Livonian is only understood by the speaker, their translator, and a few language speakers. Though Livonian does not have any functions (or, at most, only very few) associated with daily interaction, surprisingly, thanks specifically to its scientific study, it is a language with dictionaries (Kḷava 2016: 63), language corpuses, and which can fully function as a literary language; currently, these are the main factors ensuring the future development of Livonian. These are a significant aid to language learners and also contribute to the moment when a language learner is ready to become a language speaker.

The special role of Livonian in Latvia is described in the Latvian Official Language Law and in other significant national documents and normative acts. Over time, Livonian has grown into the modern Latvian culture, language, and nation far deeper and more firmly than any other language, culture, or nation in Latvia. Even if other nations might also have been in Latvia for a long time and could be called minority nations, the Livonians are something more. They are a part of the modern Latvian language and also of Latvian culture and the culture of Latvia as a whole. It seems that this has become especially noticeable in recent years when - along with Latvian society becoming better informed about the Livonians - an increasing number of people have discovered their own Livonian roots.

\section{Livonian in Latvian language policy}

In his analytical overview "Livonian in recent years", Valts Ernštreits (2016: 261) stated: "Despite the fact that in recent years there have been wide-ranging and diverse events devoted to popularizing the Livonians and the Livonian language, their combined effect, while clearly noticeable in Latvia's society, has ultimately not been effective enough. This is evidenced by the fact that within the Latvian government there is still insufficient understanding regarding the role of the Livonian language and culture in Latvia's cultural space. Within the Latvian government, Livonian culture and language are still generally viewed as something disconnected and removed from the rest of Latvia's cultural space." Indeed, despite the activities of the Livonian community, significant contributions to the field of Livonian language research, intense popularising of Livonian issues by the Latvian Language Agency, and the recent establishment of the University of Latvia Livonian Institute, some sense of alienation may still be felt between the Livonians and Latvian 
society as a whole. This situation may not be improved by governmental efforts alone; a change in public opinion is the decisive factor. Until now, the focus in public discourse concerning the Livonians has been on factual information about language, ethnodemography, history, and also on Livonian organisations and governmental support for Livonian language and culture. The development and protection measures directed to the Livonian language are largely ignoring the language situation in the Republic of Latvia - the ethnogenetic territory of both the Livonians and Latvians.

However, another approach is possible in addition to providing the necessary support for Livonian to underline its contribution to the maintenance of Latvian. Not only can the Latvian state and society provide support for Livonian culture and language, but the Livonians can provide the necessary awareness on language maintenance issues to Latvians. Namely, that information and analysis of the fate of Livonian as an endangered (but reviving) language could contribute to positive language attitudes towards Latvian in a highly competitive language situation.

\subsection{The language situation in Latvia}

The Republic of Latvia celebrated its 100th anniversary in 2018. It was founded on November 18, 1918, was occupied by the Soviet Union from 1940 to 1991, and re-established its independence on August 21, 1991. Its titular language - Latvian - belongs to the Baltic group of the Indo-European language family. The first written texts in Latvian date to the 16th century. During the last millennium, the present-day territory of Latvia was a crossroads of languages and cultures; during the last century it experienced drastic ethnodemographic and political changes placing the Latvians under threat of assimilation. In the last decades, many sociolinguistic studies on these issues have been published (Ozolins 1999, Baltinšs, Druviete, Veisbergs 2008, Hogan-Brun, Ozolins, Ramoniene, Rannut 2009, Language Situation 2012, Riekstiņš 2012, Veisbergs 2013, Language Situation 2016, Druviete, Valdmanis 2018, Druviete, Veisbergs 2018 et al.), therefore, only a few background facts are mentioned here.

As stated above, the independent Republic of Latvia came into being in 1918. This occurred as result of a favourable historical situation and the legal status of Latvian became one of the most important issues of 
its domestic policy. Several laws concerning the use of languages were passed, e. g., The Regulations of State Language Proficiency (1921) and The Law on State Language (1935). At the same time, its minority language policy was recognised as good by the League of Nations. The Latvian language operated across all sociolinguistic functions, and cultural autonomy was granted to minorities. This promising situation was ended by the 1940 incorporation of Latvia into the USSR. During the occupation, massive ethnodemographic changes took place; the number of Eastern Slavic people increased fourfold, and assymetrical Russian-Latvian bilingualism developed as a result of Soviet language policy. The Latvian language lost an increasing number of functions within Latvia's society.

The language situation in Latvia before independence could be summed up as follows: the shrinking of the sociolinguistic functions of Latvian; the ideology of Russian as the "second mother tongue"; the extensive use of Russian in administration and business; low competence in Latvian as a second language among minorities (only $20 \%$ could speak Latvian); the Russification of non-Russian minorities; and psychological resistance among Latvians, characterised by high mother tongue loyalty. The ambiguous nature of Soviet language policy (supported corpus planning vs. restricted status planning) resulted in a high linguistic quality of Standard Latvian being maintained, despite the restrictions on its use. In order to reverse this language shift, Latvian was proclaimed the sole official state language in 1988, acknowledging Latvian self-determination and the continuation of the Republic of Latvia which had been established in 1918.

As a result, the status of Latvian as the sole official state language was restored as a sign of national resistance even before independence, and in 1989 the first Language Law was adopted. Independence was regained in 1991, bringing significant changes in language policy. The pre-independence Language Law was amended in 1992. The current Official Language Law was adopted in 1999, supplemented by several Regulations by the Cabinet of Ministers. The main working document for the implementation of this law is Guidelines of State Language Policy (2010-2014, 2015-2020).

At the beginning of 2018, the population of Latvia was 1,934,370 people, which was composed of $62 \%$ Latvians, $25.2 \%$ Russians, $3.2 \%$ Belarusians, $2.2 \%$ Ukrainians, $2.1 \%$ Poles (Demography 2018: 10). The ethnodemographic composition, geopolitical situation, historical heritage, and competition with two international languages with high 
economic value - Russian and English - in the national and regional language market demands well-considered and coordinated implementation of language policy goals. The main tasks of governmental language policy institutions, such as the State Language Center and the Latvian Language Agency, are as follows: 1) to ensure the sustainability, linguistic quality, and competitiveness of the Latvian language as the state language of the Republic of Latvia and an official language of the European Union in the market of languages in Latvia and the world and 2) to guarantee the opportunity to preserve, develop, and use the languages of the minorities of Latvia - including Livonian (Druviete, Valdmanis 2018). However, we can say that a dilemma, therefore, exists for researchers and politicians: how to promote Latvian language skills, use, and positive language attitudes in a situation characterised by the full scope of minority language rights and linguistic self-sufficiency of Russian language speakers, the immigration situation, and Russia's media environment as well as the growing impact of English? The lessons provided by Livonian culture and language may be of some significance.

\subsection{Livonian - indigenous language, minority language, or something else?}

There exists extensive literature on genetic and typological descriptions of Livonian, its phonological, lexical, grammatical features as well as linguistic contacts with neighbouring languages (see Ernštreits 2016). However, very little attention has been paid to the sociolinguistic aspects of Livonian with the respect to the overall language situation of Latvia. Terminological issues play an important role here.

Livonian has been mentioned in almost all language-related legal acts adopted shortly before or after the re-establishment of independence. The Law on Languages (1989) stated: "Valsts garantē arī lībiešu kultūras saglabāšanu un attīstīšanu lībiešu valodā" / "The State guarantees also the protection of Livonian culture and its development in Livonian" (translation by the authors) (Article 15). As we see, there was no classification or explanation for such a specific role for Livonian. In the Law About the Unrestricted Development and Right to Cultural Autonomy of Latvia's Nationalities and Ethnic Groups (1991) there is preamble-like introduction: "Latvijas Republikā dzīvo latviešu nācija, sena pamattautība - lībieši, kā arī nacionālās un etniskās 
grupas" / "Within the Republic of Latvia lives the Latvian nation, the ancient indigenous nationality, the Livs, as well as other nationalities and ethnic groups" (translation by the Saeima of the Republic of Latvia, 1997). This is the first legal act recognising the Livonians as an autochthonous ethnicity. In 1992, the previous version of Article 15 of the 1989 Law on Languages had been edited: "Valsts garantē arī lībiešu valodas un kultūras saglabāšanu un attīstīšanu" / "The State also guarantees the protection and development of Livonian language and culture" (translation by the authors).

In the 1999 Official Language Law, which is still in force without amendments, there is a special section (Article 4) about the Livonian language: "Valsts nodrošina lībiešu valodas kā pirmiedzīvotāju (autohtonu) valodas saglabāšanu, aizsardzību un attīstību" / "The State shall ensure the maintenance, protection and development of the Liv language as the language of the indigenous (autochthon) population" (Official translation by the Terminology and Translation Centre, 2000). In the context of the language policy of Latvia, Article 5 is also very significant: "Ikviena cita Latvijas Republikā lietotā valoda, izñemot lībiešu valodu, šā likuma izpratnē ir uzskatāma par svešvalodu" / "Any other language used in the Republic of Latvia, except the Liv language, shall be regarded, within the meaning of this Law, as a foreign language". This is because it draws a very clear line between Livonian and other "minority" languages in Latvia.

In the Constitution of the Republic of Latvia, there is no special reference to the Livonians except a general statement in Article 114: "Personām, kuras pieder pie mazākumtautībām, ir tiesības saglabāt un attīstīt savu valodu, etnisko un kultūras savdabību" / "Persons belonging to ethnic minorities have the right to preserve and develop their language and their ethnic and cultural identity" (translation by the State Language Centre).

In 2014, after the precarious referendum on the State language of Latvia (see Druviete, Ozolins 2016), the Preamble of the Constitution was adopted: "Latvijas identitāti Eiropas kultūrtelpā kopš senlaikiem veido latviešu un lībiešu tradīcijas, latviskā dzīvesziņa, latviešu valoda, vispārcilvēciskās un kristīgās vērtības"/ "Since ancient times, the identity of Latvia in the European cultural space has been shaped by Latvian and Liv traditions, Latvian folk wisdom, the Latvian language, universal human and Christian values" (translation by the State Language Centre). The fact that in this Preamble, the Latvian language is mentioned three times demonstrates the high position of language among national identity issues. 
In other sources the terms pamattauta, pamattautība, pamatiedzīvotāji (literally - 'a basic, fundamental, founding ethnicity') have been used. The policy-planning document "Livonians in Latvia 2008-2012" describes "Lībiešu (līvu) tauta ir Latvijas sena pamattautība, kura mūsdienu Latvijas teritorijā dzīvo gadu tūkstošus" / "The Livonians/ Livs are an ancient founding nation of Latvia residing in the present territory of Latvia for thousands of years" (translation by the authors). Quite often the description "otra pamattautība"/ "the other founding nation" is used. In the recent national encyclopaedia, we also find this term "Samazinājies arī Latvijas pamattautas - lībiešu - skaits" / "The other founding nation of Latvia - the Livonians - has also decreased in number" (translation by the authors) (Nacionālā enciklopēdija 2018, 504). On the same page, the term pamattautība is also used in reference to the Latvians. The same source includes an article about the Livonian language (but not about the Livonians as an ethnicity) by Valts Ernštreits describing Livonian as "autohtona Latvijas val[oda]"/ "an autochthonous language of Latvia" (Nacionālā enciklopēdija 2018, 30).

Therefore, it can be said that there is considerable uncertainty regarding the proper terminology to use when describing the status of the Livonians as an ethnicity, especially when translation is involved. The use of the terms pamattauta, pamattautība demands some understanding of how the Latvian nation developed, and it is not that simple to translate these terms into English. The term autohtoni can be mostly used in scholarly texts and is not synonymous with pirmiedziviotajji, which itself is not identical with "First Nations", e. g., in Canada. Likewise, it is almost impossible to translate the English term indigenous into Latvian with regard to the Livonians both linguistically and politically. In recent times, indigenous has been translated, just like the term aboriginal, as aborigenni and therefore is being used contrary to its traditionally narrow meaning referring to the indigenous nations of Australia. The other proposed term iedzimtie has a rather negative connotation and is not used anymore.

UNESCO has designated 2019 as the International Year of Indigenous Languages (in Latvian - Starptautiskais pirmiedzīvotāju valodu gads). The United Nations Declaration on the Rights of Indigenous Peoples (2007) can hardly be applicable to Livonians. Do we have to celebrate this year in Latvia? Absolutely we do. This year draws attention to small threatened languages, and Livonian is among these, or, as C. Moseley called it, "the most endangered language in Europe" (Moseley 2014, $61)$. 
This year is a unique opportunity to remind everyone that "indigenous languages are not only methods of communication, but also extensive and complex systems of knowledge that have developed over millennia. They are central to the identity of indigenous peoples, the preservation of their cultures, worldviews and visions and an expression of self-determination. When indigenous languages are under threat, so too are indigenous peoples themselves" (UN 2018). This is true for all languages, including Latvian, and information about Livonian in the context of global linguistic diversity would contribute to positive language attitudes towards Latvian, too.

There is also a tendency to avoid any further definition of the sociolinguistic status of Livonian within a dichotomy of "the official (State) language vs. other languages". The Livonians and the Livonian language are usually excluded from various overviews of minorities in Latvia, and their small numbers and high level of assimilation are not the only reasons for this. For example, the Livonians are not mentioned in the article about minority cultures in the comprehensive volume "Latvia and Latvians" (Dribins, Goldmanis 2018). We have to agree that "[ $\mathrm{t}]$ he terms historical, traditional and autochthonous minorities the 'old minorities' refer to communities whose members have a distinct language, culture, or religion as compared to the rest of the population and who have become minorities through the redrawing of international borders, having seen the sovereignty of their territories shift from one country to another. It has to be noted that there is a subtle continuum between minority groups and indigenous peoples. Without entering into details in this controversial issue, it has to be admitted that the debate about the difference between indigenous peoples and minorities is indeed complex. It is not easy to distinguish between a group that calls itself an 'indigenous people' and a group or minority that recognizes itself as being native to a given territory and that invokes that characteristic in order to obtain its rights" (Medda-Windischer 2017, 25). Livonian language rights have been partly recognised by several laws and also by article 18 (4) of the Official Language Law: "Names of places, institutions, public organisations and undertakings (companies) in the Liv coastal territory, and names of events taking place in this territory, shall also be created and use thereof shall be in the Liv language" (Official translation by the Terminology and Translation Centre, 2000). The state provides support for Livonian cultural activities and language learning. Unfortunately, due to the small number of Livonian speakers and the fact that the Livonian community is scattered across 
Latvia (most Livonians live in Rīga with the next largest group living in Ventspils, and only then in the traditional Livonian area of northern Courland), a broader spectrum of implementation of Livonian rights seems almost impossible. From a sociolinguistic point of view, Livonian has to be classified as an autochthonous minority language, but other terms may be applied, too, especially politically indicative terms like (otra) pamattautība, pamattauta. More important are actions directed towards the dissemination of information about the Livonians and practical support for Livonian institutions and organisations. Public awareness of Livonian genealogical roots should also be ensured. In addition, it should be noted that, as researchers writing in the Commentaries on the Constitution of the Republic of Latvia point out, "Lỉbiešu valoda nav latviešu valodas paveids, bet īpaša, latviešu valodai neradniecīga valoda, tātad tā nebūtu saistāma ar latgaliešu rakstu valodas statusa un lietojuma problemātiku" / "Livonian is not a variety of Latvian, but a unique language not related to Latvian. Therefore, it should not be related to the issues connected with the status and use of the Latgalian written language" (translation by the authors) (Balodis 2014, 307).

\subsection{The sociolinguistic position of Latvian}

The situation of Livonian in Latvia, therefore, does not correspond to the classic model of a "majority-minority" relationship for historical as well as ethnodemographic reasons. If we wish to find parallels to the Livonian perspective among other language communities, languages such as Cornish, Scottish Gaelic, Breton in the United Kingdom and France, as well as some of the indigenous languages of Quebec, could be mentioned. From the Latvian perspective, the status of the dominant language in these situations is different. English and French are so-called world languages with millions of speakers and high economic value. But how we can describe the position of Latvian?

The precise number of Latvian speakers cannot be defined, as it does not coincide with Latvia's total population. Additionally, there is incomplete information regarding the number of speakers for whom Latvian is a native language outside of Latvia's borders, and also the number of speakers for whom Latvian is a second language. Approximately $90 \%$ of the ethnic minority community in Latvia claim knowledge of Latvian. It is estimated that approximately 370,000 Latvians live outside of Latvia (MFA 2015). Thus, taking these observations into account, 
Latvian is spoken by at least 2 million people. According to the latest edition of the Ethnologue (2018) there are only 401 languages, or 5.6\% of the 7097 living languages in the world today, which have more than 1 million speakers. This means that by virtue of its total number of speakers, Latvian finds itself among the top two hundred languages in this list, which is an excellent indicator. Languages spoken by more than one million people are mostly classified as part of the completely safe language group. According to the Expanded Graded Intergenerational Disruption Scale (EGIDS), Latvian can be classified as a Level 1 state (official) language and, therefore, as a language which cannot be endangered.

However, the total number of speakers and official status are not the only factors to be taken into account when judging language competitiveness. Latvian competes with at least 2 of the 6 global megalanguages (Russian and English). In order to understand Latvia's ethnodemographic and geopolitical situation it is not sufficient to look only at statistical data and legal acts, because these give an incomplete impression of the actual competitiveness of Latvian or its future prospects for development. Objectively measurable parameters regarding the language situation must be analysed in a wider historical and international context and in close connection with the linguistic attitudes of the speech community as derived from qualitative studies. This attitude, in turn, depends not only on narratives which have taken hold over the course of generations, and which in Latvia often are characterised by a sense of endangerment and fatalism, but also on society's knowledge of languages and their competition with each other in Latvia and in the world in general. The symbolic meaning of Latvian as part of the identity of the Latvian state is not openly doubted in most cases. But in practice, words and ideals may not always coincide with actions and reality in terms of linguistic attitudes or actual linguistic behaviour (see Language Situation 2012, Language Situation 2016). Surveys show a high level of linguistic tolerance among Latvians, but also show some features indicative of a still existing minority complex and linguistic indifference which could be harmful for the future prospects of Latvian. In this transitional situation, psychological factors are extremely important. One must take into account both the psychological resistance of Russian-speakers who, from a position of political and economic dominance have become a minority still enjoying linguistic selfsufficiency, as well as the "minority complex" of Latvians. It would be an exaggeration to speak of Livonians as "a minority within (at least 
psychologically speaking) a minority"; however, adjustments in public opinion concerning the language hierarchy of Latvia are taking place only gradually. Even after almost thirty years of re-established independence, the situation of Latvian in Latvia does not correspond to the traditional position of the official language in a unitary monolingual state.

\section{The significance of the Livonians for the Latvians}

In any publication, when speaking about Latvian ethnogenesis and the evolution of the Latvian language, the Livonians and the Livonian language are necessary parts of that discussion. Yet, at the same time, the Livonian nation and Livonian language are independent and separate entities. As stated earlier, this may be precisely the reason that language researchers seem to become stuck on fundamental points and definitions when analysing the relationship between the Livonian and Latvian languages. These include: how is Livonian to be defined within Latvia (as an autochthonous language, a minority language, do any of these terms describe its role?); does the position of Livonian correspond to existing concepts or perhaps requires a new definition to describe it appropriately; and also, how does one distinguish the Livonian spoken centuries ago, which had a significant role in the evolution of Latvian, from the modern Livonian language; and many other questions.

Therefore, the position of Livonian within Latvia should be seen from two perspectives: the preservation, development, and revitalisation of the use of Livonian as well as the mutual influence of Livonian and Latvian. Close historical ties and different societal changes throughout history are also at the foundation of a variety of changes in language, which are layered one on top of the other, thereby obscuring the signs of clear mutual influence between both languages. Thus, in order to completely understand the nature of Latvian, it is necessary to research and understand the nature of Livonian - irrespective of the total number of Livonians or the activities of their community.

2011 was designated the International Year of Livonian Language and Culture with a wide-ranging programme of events taking place in Latvia as well as abroad. The extensive "Livonian-Estonian-Latvian Dictionary" was published in 2012. The comprehensive collection of articles "The Livonians. History, language, and culture" was published in Estonian in 2011 and in Latvian in 2013. Information about the 
Livonians is included in the Latvian Culture Canon (https://kulturaskanons.lv/archive/libiesu-kultura/). In December 2018, a special 3-yearlong governmental research programme "The Latvian Language" was launched. One of its ten sub-programmes is devoted to studies of Livonian using modern technology. As C. Moseley states in writing about Livonian, "not many languages are so well equipped to be revitalised" (Moseley 2016, 250).

Currently, an increasing number of people are becoming involved in sharing information about the Livonians. For example, the modern theatre programme "Latest", which came about through cooperation between the New Theatre Institute of Latvia and "Kanuti Gildi SAAL" of the Tallinn Theatre. They presented a lecture about the Livonians describing them as a point of contact between the national cultures of the Latvians and Estonians as well as a major issue to be addressed and as a cultural anthropological object of study. It was "jaunu cilvēku skatījums uz lībiešu asimilācijas situācijas vēsturi, mēǵinot jautājumu aplūkot arī filozofiskā līmenī: vai minoritāras kultūras, valodas un nācijas izzušana ir vai nav dabisks process, un kā pret to attiekties" / "the perspective of young people on the history of Livonian assimilation, attempting to view the question on a philosophical level: is the disappearance of a minority culture, language, and nation a natural process or not, and how should one relate to it" (translation by the authors). The reviewer Lauma Mellēna-Bartkeviča concluded: "Pēcgaršā kvēl neizteiktais eksistenciāla rakstura jautājums, uz kuru negribas atbildēt: vai mēs, mazās Baltijas tautas un simtgadi sasniegušās nācijas, varam būt nākamie, kas aizies pa lībiešu celı?u?" / "A question of an existential nature burns on the palate, and it is one that one does not wish to answer: will we, the small nations of the Baltic and the states that have reached their centenaries, be the next to go down the same road as the Livonians?" (translation by the authors) (Mellēna-Bartkeviča 2018). The answer to this question will depend not only on the objective sociolinguistic situation, but also and primarily on the language attitudes of the Latvians themselves. "Būtiski ir ņemt vērā lībiešu pieredzi, jo lībieši ir latviešu miniatūrais modelis gan sabiedrības, gan valodas ziņā, atšķirība ir tikai skaitļos. Lībiešu attīstība līdz šim punktam, kurā atrodamies, ḷoti labi parāda, kāds ir tas process. Un kas notiek, ja neko nedara." / "It is fundamental to take into account the Livonian experience, as the Livonians are a miniature model of the Latvians in terms of society as well as language, the only difference is found in their numbers. The development of the Livonians up to the point where we find ourselves now, shows the nature of that 
process very well. And also what happens if one does nothing." (translation by the authors) (Ernštreits 2012b).

The newly founded Livonian Institute works under the auspices of the University of Latvia and the Microsoft Innovation Centre. There is deeply rooted symbolism in this fact. Will Livonian issues become a source for innovation in the political and linguistic landscape of Latvia? Will they bring about an innovation in thinking and attitudes? Such an approach would favour both the revival of Livonian and also aid the long-term maintenance of Latvian within the global competition of languages and cultures.

\section{Acknowledgements}

This study was supported by the Latvian Ministry of Education and Science research programme "Latvian language" (VPPIZM-2018/2-0002).

\section{Addresses:}

Ina Druviete

University of Latvia

Raina Blvd 19, Riga

LV-1586

E-mail: ina.druviete@1u.lv

Gunta Kḷava

Livonian Institute

University of Latvia

Kronvalda Blvd 4-220, Riga

LV-1010

E-mail: gunta.klava@valoda.lv

\section{References}

Balodis, Ringolds, ed. (2014) Latvijas Republikas Satversmes komentāri. Ievads. I nodaļa. Vispārējie noteikumi. Rīga: Latvijas Vēstnesis.

Baltiņš, Māris, Ina Druviete, and Andrejs Veisbergs, eds. (2008) Break-out of Latvian: a sociolinguistic study of situation, attitudes, processes, and tendencies. Rīga: Zinātne. 
Blumberga, Renāte (2013) “Lībieši 19.-21. gadsimtā”. In Renāte Blumberga, Tapio Mekeleinens and Karls Pajusalu. Lìbieši. Vēsture, valoda un kultūra, 169-204. Rīga: Līvõ Kultūr sidām.

Census $(2011)=$ Tautas skaitǐšana. Centrālā statistikas pārvalde. Available online at $<$ https://www.csb.gov.lv/lv/statistika/statistikas-temas/iedzivotaji/tautas-skaitisana/ tabulas/tsg 11-06/latvijas-pastavigie-iedzivotaji-pec $>$. Accessed on 15.11.2018.

Demography $(2018)=$ Demography 2018. Collection of statistics. Rīga: Central Statistical Bureau of Latvia.

Dribins, Leo and Juris Goldmanis (2018) "National minority cultures in Latvia". In Latvia and Latvians. Vol. 2, 837-881. Rīga: Latvian Academy of Sciences.

Druviete, Ina and Uldis Ozolins (2016) "The Latvian referendum on Russian as a second state language. February 2012”. Language Problems and Language Planning 40, 2, 121-145.

Druviete, Ina and Jānis Valdmanis (2018) "The role of national language policy institutions in the implementation of the Law on the Official State Language in Latvia". In Gerhard Stickel, ed. National language institutions and national languages. Contributions to the EFNIL Conference 2017 in Mannheim, 145-156. Budapest: Research Institute for Linguistics.

Druviete, Ina and Andrejs Veisbergs (2018) “The Latvian language in the 21st century". In Latvia and Latvians. Vol. 1, 244-278. Rīga: Latvian Academy of Sciences.

Ernštreits, Valts (2012a) "Development of the Liv language situation in Latvia". In Language situation in Latvia: 2005-2010, 150-173. Rīga: Latvian Language Agency.

Ernštreits, Valts (2012b) "Lībieši ir latviešu miniatūrais modelis". Latvijas Avīze. Available online at $<$ https://www.la.lv/valts-ernstreits-libiesi-ir-latviesu-miniaturais-modelis $>$. Accessed on 30.11.2018.

Ernštreits, Valts (2016) "Livonian in recent years". Journal of Estonian and FinnoUgric Linguistics (ESUKA - JEFUL) 7, 1, 257-274.

Ernštreits, Valts (2017) “The development of the Livonian language". In Language situation in Latvia: 2010-2015, 195-218. Rīga: Latvian Language Agency.

Ethnologue 2018 = "Summary by language size". Ethnologue: languages of the world. 21 st ed. Simons, Gary F. and Charles D. Fennig, eds. Dallas, Texas: SIL International. Available online at $<$ https://www.ethnologue.com/statistics/size $>$. Accessed on 30.11.2018.

Hogan-Brun, Gabrielle, Uldis Ozolins, Meilute Ramoniene, and Mart Rannut (2007) "Language politics and practices in the Baltic States". Current Issues in Language Planning 8, 4, 469-631.

Kḷava, Gunta (2016) "Lībiešu vārdnīcu gadsimta ceturksnis - no sarunvārdnīcas līdz zinātniskai valodas attīstībai”. Lìvlizt āigastrōntõz = Lībiešu gadagrāmata 2016, 58-65. Rīga: Līvu (Lībiešu) savienība "Līvõd İt".

Language situation 2012 = Language situation in Latvia 2005-2010. Rīga: Latvian Language Agency, 2012.

Language situation 2016 = Language situation in Latvia 2010-2015. Rīga: Latvian Language Agency, 2016. 
Livones = "Lībiešu valoda". Livones. Available online at http://www.livones.net/lv/valoda/?libiesu-valoda>. Accessed on 20.11.2018.

Medda-Windischer, Roberta (2017) "Old and new minorities: diversity governance and social cohesion from the perspective of minority rights". Acta Univ. Sapientiae, European and Regional Studies 11, 25-42.

Mellēna-Bartkeviča, Lauma (2018) "Lībiešu jautājums". Satori. Available online at $<$ https://www.satori.lv/article/libiesu-jautajums $>$. Accessed on 30.11.2018.

MFA 2015 = Latvijas diaspora pasaulē. Ministry of Foreign Affairs. Available online at $<$ http://www.mfa.gov.lv/tautiesiem-arzemes/latvijas-diaspora-pasaule $>$. Accessed on 20.11.2018.

Moseley, Christopher (2014) "Livonian - the most endangered language in Europe?". Journal of Estonian and Finno-Ugric Linguistics (ESUKA - JEFUL) 5, 1, 61-75.

Moseley, Christopher (2016) "Revitalizing a community language: Livonian and other community languages". Journal of Estonian and Finno-Ugric Linguistics (ESUKAJEFUL) 7, 1, 249-255.

Nacionālā enciklopēdija 2018 = Latvija. Nacionālā enciklopēdija (2018) Rīga: Latvijas Nacionālā bibliotēka.

Ozolins, Uldis (1999) "Between Russian and European hegemony: current language policy in the Baltic States". Current Issues in Language and Society 6, 1, 6-47.

Riekstiņš, Jānis (2012) In defence of the Latvian language against Russification. 19441989. Documents. Rīga: Latvian Language Agency.

Sarivaara, Erika, Satu Uusiautti, and Kaarina Määttä (2013) "How to revitalize an indigenous language? Adults' experiences of the revitalization of the Sámi language". Cross-cultural Communication 9, 1, 13-21.

UN 2018 = The United Nations Permanent Forum on Indigenous Issues. Available online at $<$ https://www.un.org/development/desa/indigenouspeoples/wp-content/ uploads/sites/19/2018/04/Indigenous-Languages.pdf $>$. Accessed on 30.11.2018.

Veisbergs, Andrejs (2013) "Reality and perceptions of multilingualism in the Baltic States". Humanities and Social Sciences. Latvia 21, 1, 52-71.

Viitso, Tiit-Rein (2012) Līvõkiel-ēstikiel-leţkiel sõnārōntõz. Liivi-eesti-läti sõnaraamat. Lībiešu-igauņu-latviešu vārdnīca. Toimetamine ja läti vasted / Redaktors un latviešu daļas autors Valts Ernštreits. Tartu and Rīga.

\section{Kokkuvõte. Ina Druviete, Gunta Kḷava: Liivi keele roll Lätis sotsioling-} vistilisest perspektiivist. Artikkel käsitleb liivi keele rolli tänapäeva Lätis, esitades liivi keele olukorra lühikirjelduse läti keele olukorra ja aktuaalsete sotsiolingvistiliste probleemide kontekstis. Lisaks liivi keele ja kultuuriga seonduva Läti seadusandluse kajastamisele on artiklis visandatud võimalused liivi keele õiguste realiseerimiseks, pöörates laiemat tähelepanu liivlaste kui rahva ja liivi keele probleemide mõistmisele, samuti pakkudes olukorrale vastavat terminite kasutust. Võib järeldada, et liivlased Lätis ei vasta terminile 'vähemusrahvas'. Liivlased on midagi enamat, nad on kaasaegse läti keeleruumi osa ja ka Läti kultuuri osa tervikuna. Samal ajal on liivlased rahvana ja liivi keel eraldi 
iseseisev üksus. Seetõttu tuleks liivi keele positsiooni Lätis vaadelda kahest vaatevinklist: ühelt poolt on oluline liivi keele kasutuse säilitamine, arendamine ja taaselustamine, teisalt läti ja liivi keele omavahelise mõju jälgimine.

Märksõnad: keele püsimine, keelepoliitika, keelesituatsioon, keele staatus, läti keel, liivi keel

Kubbõvõttõks. Ina Druviete, Gunta Kḷava: Līvõ kīel jag Lețmōl sotsiolingvistik perspektīvst. Kēra nīžõb iḷ līvõ kīel jag tämpiz Lețmōl, tarmõb il̦vaņtlõks iḷ līvõ kīel vỏlmiz Lețmōl lețkīel ja sīe tämpizt sotsiolingvistik problēmõd kontekstõs. Lețmō pandõkst sizzõl kēratõd līvõ kīel ja kultūr status kūoral kēra nīžõb iḷ võimizt līvõ kīel õigõmd kỗlbatimiz pierāst, īžkizt vanttlõs līvõd rov ja līvõ kīel mūoštamizt, ja tarmõs terminidi līvõd tämpiz kỗrda pierāst. Võib kītõ, ku Lețmōl līvlizt pierāst äb kõlb termin 'minoritāt'. Līvõd ātõ midāgõst jemīn, ne ātõ tämpiz lețkīel jag ja ka Lețmō kultūr jag amnämnizt. Sīel īž āigal līvõd nemē rovz um ka īžpīliji ažā. Siepierāst līvõ kīeldõ Lețmōl vỏlks vaņtlõmõst kōdst aspektõst: līvõ kīel kỗlbatimiz praț̦imi, kazāntimi ja ūd päl jellõ kutsimi ìdst pūolst, ja līvõ ja lețkīel eņtšvailizt mỏjjimizt tuoizõst pūolst. 